\title{
Dual-Use Bioenergy-Livestock Feed Potential of Giant Miscanthus, Giant Reed, and Miscane
}

\author{
David M. Burner'†, Amanda J. Ashworth ${ }^{2 *}$, Daniel H Pote1, Jim R. Kiniry3 ${ }^{3}$, David P. Belesky4, \\ James H. Houx III ${ }^{5}$, Paul Carver 6 , Felix B. Fritschi ${ }^{5}$
}

${ }^{1}$ US Department of Agriculture, Agricultural Research Service, Dale Bumpers Small Farms Research Center, Booneville, AR, USA ${ }^{2}$ US Department of Agriculture, Agricultural Research Service, Poultry Production and Products Safety Research, Fayetteville, AR, USA

${ }^{3}$ Grassland Soil and Water Research Laboratory, USDA ARS, Temple, TX, USA

${ }^{4}$ West Virginia University, Plant \& Soil Sciences, Morgantown, WV, USA

${ }^{5}$ Division of Plant Sciences, University of Missouri, Columbia, MO, USA

${ }^{6}$ New Energy Farms, Leamington, Canada

Email: *Amanda.Ashworth@ars.usda.gov

How to cite this paper: Burner, D.M., Ashworth, A.J., Pote, D.H., Kiniry, J.R., Belesky, D.P., Houx, III, J.H., Carver, P. and Fritschi, F.B. (2017) Dual-Use Bioenergy-Livestock Feed Potential of Giant Miscanthus, Giant Reed, and Miscane. Agricultural Sciences, 8, 97-112.

http://dx.doi.org/10.4236/as.2017.81008

Received: December 23, 2016

Accepted: January 20, 2017

Published: January 23, 2017

Copyright $\odot 2017$ by authors and Scientific Research Publishing Inc. This work is licensed under the Creative Commons Attribution International License (CC BY 4.0).

http://creativecommons.org/licenses/by/4.0/

(c) (i) Open Access

\begin{abstract}
High yielding perennial grasses could integrate bioenergy-livestock operations, thereby, offsetting diversions of cropland to lignocellulosic crops, but research is needed to determine chemical composition and digestibility of leaf and stem fractions that might affect downstream reside uses. The objective of this study was to compare feedstock quality of leaf and stem tissues of dedicated bioenergy feedstocks: giant miscanthus (Miscanthus $\times$ giganteus), giant reed (Arundo donax), and miscane (Saccharum hybrid $\times$ Miscanthus spp.) when grown with or without supplemental irrigation on an upland site. Three species were space-planted on a silt loam soil in March 2007 and harvested prior to the first freeze in plant-cane, first ratoon, and second-ratoon crops for three years. Giant miscanthus leaf tissue had greatest acid detergent lignin and cellulose, and lowest concentrations of nitrogen $(\mathrm{N})$ and total nonstructural carbohydrates (TNC) in ratoon crops. Giant reed leaf tissue had greatest concentrations of in vitro digestible dry matter (IVDMD), TNC, and $\mathrm{N}(\mathrm{P} \leq 0.05)$. Conversely, miscane stem tissue had greatest concentrations of IVDMD, TNC, hemicellulose, and low dry matter and combustible energy ( $\mathrm{P}$ $\leq 0.05$ ). Results suggest all species' residue has positive feedstock attributes for thermochemical bioenergy conversion, and albeit giant miscanthus has very little potential value as fodder. Miscane stem and giant reed leaf tissue have potential value as livestock feed, although giant reed is not currently recommended for planting. Further research is needed on dietary composition, acceptability, voluntary intake, and live weight gain before any of these species are recommended as livestock feed sources.
\end{abstract}




\section{Keywords}

Arundo donax, Invasive Species, Miscanthus $\times$ giganteus, Agricultural Residue, Nutritive Value, Saccharum spp. Hybrid, Tissue Components, Thermochemical Conversion, Feedstock Traits

\section{Introduction}

Compared with their first-generation biofuel counterparts, second-generation biomass crops require fewer inputs, produce greater energy on a landmass basis, reduce greenhouse gas emissions, and do not directly compete for arable land for food production [1] [2]. As much as 21.3 million ha of existing agricultural land in the US has been projected for conversion to perennial grass feedstocks [3], therefore, second-generation feedstock crops may indirectly compete for hay and grazing landmass. Therefore, in order to transform the forage-livestock industry towards second-generation biofuels without affecting grassland resources for animal operations, identifying dual-use perennial forage feedstocks is key.

Small commercial farms, those with gross cash farm income from $\$ 10,000$ to $\$ 249,999$, account for $36 \%$ of all farms and $22 \%$ of total agricultural production in the US, but they are challenged to remain profitable [4]. A new market for grassland agriculture is emerging because the Energy Independence and Security Act will require 36 billion gallons of renewable fuels by 2022 [5]. To meet this

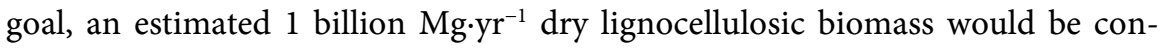
verted to renewable, liquid biofuels [6].

There are approximately 746,000 small farms in the US [7], and many of those could benefit from an integrated, dual-use, bioenergy-livestock production system. Considering, bioenergy-livestock feeds could produce sustainable yields of combustible energy (high thermal output) or be fed to livestock [2] [6] [8]. Producers that adopt this multifunctional practice could make fairly short-term management decisions to shift between commodities (bioenergy or livestock feed) based on markets, thereby minimizing risk and maximizing production efficiency [9]. For switchgrass (Panicum virgatum L.) and other perennial forage species, usage is primarily driven by cattle (Bos L. spp.) weight gains or hay sales, but bioenergy could provide a secondary market option [10]. It is less clear; however, if perennial grasses traditionally considered dedicated bioenergy feedstocks offer a secondary market as livestock feed.

Commercially, sugarcane (Saccharum L. spp.) leaves are mechanically separated from stems during harvest, a convenient technology, whereby leaf tissue could be diverted to bioenergy or livestock feed uses [11] as has been done with maize (Zea mays L.)-stover [12] [13]. The fibrous, lignocellulosic components of plant cell walls (cellulose and hemicellulose) can produce substantial amounts of 5 and 6 carbon sugars [6] [14]. For instance, [15] found that whole-plant (leaf and stem) conversion of giant miscanthus (Miscanthus $\times$ giganteus J.M. Greef \& Deuter ex Hodkinson \& Renvoize), giant reed (Arundo donax L.), and sugarcane 
yields ranges from 0.29 to $0.33 \mathrm{~g}$ glucose $\mathrm{g}^{-1}$ dry mass, or is about $0.1 \mathrm{~g}$ bioethanol g ${ }^{-1}$ dry mass.

Plant tissue can differ in various feedstock quality attributes including concentrations of primary metabolites, fiber, gross energy density, and digestibility; which can impact their downstream value and use. Some types of sugarcane, i.e. energy cane, differs from commercial sugarcane by having high stalk fiber concentrations [16] and some [Saccharum sp. $\times$ Miscanthus sp. (miscane)] reportedly have lower leaf ash and $\mathrm{N}$ concentrations than switchgrass and giant miscanthus [17], which are desirable feedstock attributes. Further, harvest timing influences tissue composition, as delayed harvests allow leaf nutrients to translocate to stems or rhizomes, or are sloughed off as leaf litter [18].

Limited information is available on the potential of giant miscanthus and giant reed to serve as livestock feed. Giant reed is invasive in many riparian areas [19] [20] [21], but could serve as an animal fodder or bioenergy resource during its eradication [22]. Fresh, whole-chopped sugarcane is similar to other roughage sources, like cottonseed (Gossypium hirsutum)-hulls, when fed to cattle [11]. Sugarcane has adequate in vitro dry matter digestibility (IVDMD) for livestock [23], and IVDMD of miscane can exceed that of giant miscanthus and switchgrass in Florida [17]. Similarly, adequate IVDMD concentration has been reported for giant reed leaves in Georgia [24], while that of giant miscanthus and giant reed stems are quite low, even for C4 grasses [24] [25] [26].

Given the history of cultivation and use of perennial grasses [2], an existing knowledge base on cultural practices, availability of harvesting technology, and familiarity with livestock production, small farmers might transition to a dualuse system if given a bioenergy market option. Thus, research is needed on chemical composition of leaf and stem tissue of perennial grasses that might be used in dual-use, bioenergy-livestock feed practices, as concentrations of primary plant metabolites in leaf and stem tissues could affect their ultimate utilization. The objective of this study was therefore to compare feedstock quality of leaf and stem tissues of dedicated bioenergy feedstocks (giant miscanthus, giant reed, and miscane) when grown with or without supplemental irrigation on an upland site.

\section{Materials and Methods}

\subsection{Experimental Description and Management}

Giant miscanthus, miscane, and giant reed were grown on an upland Leadvale silt loam soil (fine-silty, siliceous, thermic Typic Fragiudult) with a fragipan at 0.4 to $0.6 \mathrm{~m}$ depth near Booneville, Arkansas $\left(35.08^{\circ} \mathrm{N}, 93.98^{\circ} \mathrm{W}\right)$. In the fall of 2006, giant miscanthus rhizomes (proprietary clone Q4264, Biomass Industrial Crops, Ltd., United Kingdom), axillary internode buds of miscane (sugarcane clone US84-1028; F1 hybrid of Saccharum hybrid $\times$ Miscanthus spp. bred and selected at US Department of Agriculture, Agricultural Research Service, Canal Point, Florida), and giant reed (originally obtained from a riparian area along the Little River near Temple, Texas) were transplanted in the greenhouse. Further information on the selected varieties can be found in [27]. On 29 March 
2007, greenhouse-grown clones of the three species were planted as split plots in four replications under either rainfed or irrigated whole plots. Split-plots consisted of 5 clones of each species arranged in a single row and spaced $1 \mathrm{~m}$ apart. Rows of split-plots were spaced $2.5 \mathrm{~m}$ apart and were randomly arranged within main plots. Plants of the respective species were planted at the ends of each split-plot and two rows of sugarcane were planted between main plots.

Weed control was conducted annually in May with applications of atrazine [2-chloro-4-(ethylamino)-6-(isopropylamino)-s-triazine] at $1.12 \mathrm{~kg}$ ai ha $\mathrm{ha}^{-1}$, and was supplemented by manual weeding as needed. During spring green-up, all plots were fertilized with $80 \mathrm{~kg} \mathrm{~N} \mathrm{ha}{ }^{-1}$ in the form of ammonium nitrate $\left(\mathrm{NH}_{4} \mathrm{NO}_{3}\right)$ and $60 \mathrm{~kg} \mathrm{P} \mathrm{ha}^{-1}\left(\mathrm{P}_{2} \mathrm{O}_{5}\right)$, and $100 \mathrm{~kg} \mathrm{~N} \mathrm{ha}^{-1}\left(\mathrm{NH}_{4} \mathrm{NO}_{3}\right)$ was applied in both 2008 and 2009. In irrigated whole plots, precipitation was supplemented during the growing season by additions of 719,580 , and $690 \mathrm{~mm}$ irrigations during 2007, 2008, and 2009, respectively. To provide irrigation, soaker hoses were installed for each irrigated row and water was applied three times per week except when a rainfall event exceeding $12 \mathrm{~mm}$ occurred.

\subsection{Biomass Sampling and Tissue Analyses}

A representative 2-stalk (giant reed and miscane) or 4-stalk (giant miscanthus) sample was taken $0.15 \mathrm{~m}$ above soil surface on plant-cane (establishment year) (PC, 29 October 2007), first-ratoon [or subsequent shoots sprouting from plant base (FR, 27 October 2008)], and second-ratoon (SR, 19 November 2009) crops prior to the first frost. Samples were separated (split-split plot) into leaf lamina (leaf) and stem plus leaf sheath tissue components (stem), and dried at $60^{\circ} \mathrm{C}$. Plant residue tissue samples were ground to $1 \mathrm{~mm}$ particle size on a Wiley mill (Arthur Thomas Co., Philadelphia, Pennsylvania) and stored at $-20^{\circ} \mathrm{C}$ until laboratory analysis. Tissue sample $\mathrm{N}$ analyses were conducted by combustion (Vario Macro CN, Elementar Americas, Inc., Mt. Laurel, New Jersey). The concentration of IVDMD was determined using the procedure of [28] modified for the Ankom Daisy II fiber analyzer \#F200 (Ankom Technology, Macedon, New York). Source of fluid for IVDMD analysis was a ruminally-cannulated steer (Bos taurus L.) adapted for $10 \mathrm{~d}$ to a basal diet of cracked maize and common bermudagrass (Cynodon dactylon L.) hay (15:85 ratio of grain:hay, w:w), and allowed ad libitum access to fresh water.

Cellulose, hemicellulose, and acid detergent lignin (ADL) concentrations were determined by mass loss during sequential treatment of samples in acid detergent solution ( $72 \%$ v: $\mathrm{v}_{2} \mathrm{SO}_{4}$ ), and combustion at $550^{\circ} \mathrm{C}$ following methods described by Ankom Technology for the Filter Bag Method. Specifically, bags were agitated every 30 mins by manually pushing a $2 \mathrm{~L}$ beaker up and down. After 3 hrs, samples were removed and rinsed with water to remove acid. Rinses were repeated until $\mathrm{pH}$ was neutral, then samples were rinsed with acetone for 2 - 3 mins and then air dried. Thereafter, drying was completed in a batch oven at $105^{\circ} \mathrm{C}$ for $2 \mathrm{hrs}$, then placed in a desiccator until cooled to ambient temperature and re-weighed. Acid detergent lignin is acid insoluble residue minus ash [28]. 
Cellulose was calculated as [1] and hemicellulose was calculated as [2].

[Acid detergent fiber $(\mathrm{ADF})-\mathrm{ADL}]=$ cellulose.

[Neutral detergent fiber $(\mathrm{NDF})-\mathrm{ADF}]=$ hemicellulose.

For analysis of total nonstructural carbohydrates (TNC), samples were further ground to $0.5 \mathrm{~mm}$ particle size on an Udy cyclone sample mill (Seedburo Equipment Co., Chicago, Illinois). Total nonstructural carbohydrate concentrations were determined using an automated hydrolysis method [29]. Dry samples were combusted at $550^{\circ} \mathrm{C}$ to measure mineral ash residue.

Gross calorific value (combustible energy, $\mathrm{MJ} \cdot \mathrm{kg}^{-1}$ ) was measured using a bomb calorimeter (IKA C2000, IKA Works; Wilmington, North Carolina). The procedure used 10 ignitions of $\mathrm{C}_{6} \mathrm{H}_{5} \mathrm{COOH}$ standard according to ASTM International [30]. Briefly, a 0.50-g sample was pelletized, weighed to 5 decimal places, and combusted in purified $\mathrm{O}_{2}$ atmosphere. To account for $\mathrm{HNO}_{3}$ formed during combustion, the inside of the vessel and the crucible and components were rinsed into a beaker with $\mathrm{H}_{2} \mathrm{O}$ purified by a Labconco Water Pro PS (Labconco Corp, Kansas City, Missouri) 4-stage purification system $\left(18.1 \mathrm{M} \Omega \cdot \mathrm{cm}^{-1}\right.$ resistivity). Two drops of methyl red titration indicator were added to the beaker and the solution was titrated with $0.035 \mathrm{M} \mathrm{Na}_{2} \mathrm{CO}_{3}$ solution.

\subsection{Statistical Analyses}

Analysis of variance tests of feedstock quality characteristics were performed using a mixed linear model procedure, Proc Mixed in SAS v.9.2 [31] [32], with irrigation treatment (whole-plot), species (split-plot), tissue component (splitsplit plot), year, and their interactions as fixed effects, and replication as a random effect. Species within replication and year was the repeated measure with a first-order autoregressive covariance structure and restricted maximum likelihood estimation method [31] [32]. When main effect differences were found, pair-wise post hoc comparisons were performed using Least Square Means using the Tukey Honest Significant Difference test (HSD) at a Type I error rate of 5\%.

\section{Results and Discussion}

Overall results revealed significant effects for year, plant residue component (leaf and stem), and species for all traits examined (Table 1). Irrigation main effects impacted $(\mathrm{P}<0.05)$ TNC, ADL, cellulose, and energy density but not IVDMD, hemicellulose, ash, and N. Because a large number of two and three-way interaction effects were significant, results herein are focused on significant three-way interactions involving species as follows: year $\times$ tissue $\times$ species for IVDMD, $\mathrm{ADL}$, and $\mathrm{N}$; and tissue $\times$ species $\times$ irrigation for $\mathrm{TNC}$, cellulose, and gross energy density. Since these three-way interactions were not significant for hemicellulose and ash, tissue $\times$ species interactions are highlighted herein for these two traits.

\subsection{Digestibility}

Across the three years, IVDMD for the three species ranged from 330 to 672 
Table 1. Probability values from analysis of variance of in vitro dry matter digestibility (IVDMD), total nonstructural carbohydrates (TNC), acid detergent lignin (ADL), hemicellulose (Hemi), cellulose (Cell), ash, nitrogen $(\mathrm{N})$, and energy in response to year $(\mathrm{Y})$, residue tissue component $(\mathrm{T})$, species $(\mathrm{S})$, and irrigation (I) fixed effects.

\begin{tabular}{ccccccccc}
\hline Effect & IVDMD & TNC & ADL & Hemi & Cell & Ash & N & Energy \\
\hline Year (Y) & $<0.001$ & $<0.001$ & $<0.001$ & 0.050 & $<0.001$ & 0.001 & $<0.001$ & 0.012 \\
Tissue (T) & $<0.001$ & $<0.001$ & $<0.001$ & $<0.001$ & $<0.001$ & $<0.001$ & $<0.001$ & $<0.001$ \\
Y $\times$ T & $<0.001$ & $<0.001$ & $<0.001$ & 0.025 & $<0.001$ & 0.039 & $<0.001$ & $<0.001$ \\
Species (S) & $<0.001$ & $<0.001$ & $<0.001$ & $<0.001$ & $<0.001$ & 0.001 & $<0.001$ & $<0.001$ \\
Y $\times$ S & $<0.001$ & $<0.001$ & 0.101 & 0.776 & $<0.001$ & 0.838 & $<0.001$ & 0.604 \\
T $\times$ S & $<0.001$ & $<0.001$ & $<0.001$ & $<0.001$ & $<0.001$ & 0.002 & $<0.001$ & $<0.001$ \\
Y $\times$ T $\times \mathrm{S}$ & 0.002 & $<0.001$ & $<0.001$ & 0.835 & $<0.001$ & 0.810 & $<0.001$ & $<0.001$ \\
Irrigation (I) & 0.109 & 0.026 & 0.021 & 0.220 & $<0.001$ & 0.205 & 0.071 & 0.024 \\
$\mathrm{Y} \times \mathrm{I}$ & 0.068 & 0.061 & 0.440 & 0.020 & $<0.001$ & 0.427 & 0.475 & 0.304 \\
$\mathrm{~T} \times \mathrm{I}$ & $<0.001$ & 0.056 & 0.362 & 0.047 & 0.834 & 0.258 & 0.100 & 0.056 \\
$\mathrm{Y} \times \mathrm{T} \times \mathrm{I}$ & $<0.001$ & 0.017 & 0.004 & 0.049 & $<0.001$ & 0.050 & 0.053 & $<0.001$ \\
$\mathrm{~S} \times \mathrm{I}$ & 0.532 & 0.966 & 0.646 & 0.726 & 0.691 & 0.818 & 0.042 & $<0.001$ \\
$\mathrm{Y} \times \mathrm{S} \times \mathrm{I}$ & 0.774 & 0.215 & 0.645 & 0.973 & 0.254 & 0.798 & 0.553 & 0.512 \\
$\mathrm{~T} \times \mathrm{S} \times \mathrm{I}$ & 0.087 & 0.005 & 0.092 & 0.974 & 0.047 & 0.304 & 0.791 & $<0.001$ \\
$\mathrm{Y} \times \mathrm{T} \times \mathrm{S} \times \mathrm{I}$ & 0.527 & 0.042 & 0.941 & 0.928 & 0.292 & 0.704 & 0.309 & 0.033 \\
\hline
\end{tabular}

$\mathrm{g} \cdot \mathrm{kg}^{-1}$ for leaf tissue and 193 to $547 \mathrm{~g} \cdot \mathrm{kg}^{-1}$ for stem residue (Table 2). In general, average leaf IVDMD (539 g. $\mathrm{kg}^{-1}$ ) was greater than stem IVDMD concentrations $\left(386 \mathrm{~g} \cdot \mathrm{kg}^{-1}\right)$. Specifically, giant reed had greater leaf IVDMD $\left(>642 \mathrm{~g} \cdot \mathrm{kg}^{-1}\right)$ than giant miscanthus and miscane, and miscane had greatest stem IVDMD concen-

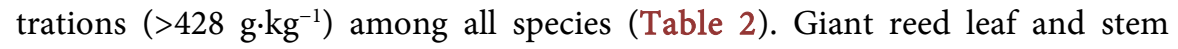
IVDMD concentrations were stable across years, whereas giant miscanthus stem IVDMD concentration decreased with every season. Giant miscanthus also had lower ratoon leaf $\left(<495 \mathrm{~g} \cdot \mathrm{kg}^{-1}\right)$ and ratoon stem IVDMD concentrations $(<303$ $\left.\mathrm{g} \cdot \mathrm{kg}^{-1}\right)$ than other species.

In vitro dry matter digestibility is a function of soluble cellular components including TNC and crude protein (CP) as well as variable amounts of cell wall constituents (CP, cellulose, and hemicellulose) that are readily degraded by rumen microorganisms [33]. Thus, high stem IVDMD of miscane may have been due to greater soluble sugars and a less lignified parenchyma than stems of other species. Greater concentrations of stem IVDMD in miscane than giant miscanthus and switchgrass is consistent with previous reports [17]. While primarily a livestock feed attribute, IVDMD concentration has been indirectly linked to methane production [34] and positively associated with bioethanol production [24]. Nonetheless, despite its high stem IVDMD, miscane productivity is low at this latitude because of poor ratooning [27]. 
Table 2. Concentrations of in vitro dry matter digestibility (IVDMD), acid detergent lignin $(\mathrm{ADL})$, and nitrogen $(\mathrm{N})$ as affected by the crop $\times$ tissue $\times$ species interaction.

\begin{tabular}{|c|c|c|c|c|c|}
\hline Tissue & Species & Crop & IVDMD & $\mathrm{ADL}$ & $\mathrm{N}$ \\
\hline & & & & $\left(\mathrm{g} \cdot \mathrm{kg}^{-1}\right)$ & \\
\hline \multirow[t]{9}{*}{ Leaf } & Giant miscanthus & $\mathrm{PC}^{\mathrm{a}}$ & $478.8 c^{b}$ & $91.5 \mathrm{c}$ & $17.5 \mathrm{c}$ \\
\hline & Giant reed & $\mathrm{PC}$ & $672.2 \mathrm{a}$ & $107.9 \mathrm{~b}$ & $27.6 \mathrm{a}$ \\
\hline & Miscane & $\mathrm{PC}$ & $503.1 \mathrm{c}$ & $67.8 \mathrm{e}$ & $15.1 \mathrm{de}$ \\
\hline & Giant miscanthus & FR & $494.7 \mathrm{c}$ & $111.5 \mathrm{~b}$ & $11.3 \mathrm{f}$ \\
\hline & Giant reed & FR & $667.4 \mathrm{a}$ & $110.9 \mathrm{~b}$ & $22.8 \mathrm{~b}$ \\
\hline & Miscane & FR & $587.0 \mathrm{~b}$ & $70.9 \mathrm{de}$ & $13.6 \mathrm{e}$ \\
\hline & Giant miscanthus & SR & $329.9 \mathrm{~d}$ & $125.1 \mathrm{a}$ & $4.4 \mathrm{~g}$ \\
\hline & Giant reed & SR & $642.4 \mathrm{a}$ & $108.1 \mathrm{~b}$ & $16.1 \mathrm{~cd}$ \\
\hline & Miscane & SR & $469.7 \mathrm{c}$ & $80.2 \mathrm{~d}$ & $11.1 \mathrm{f}$ \\
\hline \multirow[t]{9}{*}{ Stem } & Giant miscanthus & $\mathrm{PC}$ & $396.4 \mathrm{bc}$ & $98.7 \mathrm{a}$ & $6.0 \mathrm{~b}$ \\
\hline & Giant reed & $\mathrm{PC}$ & $361.0 \mathrm{~cd}$ & $72.2 \mathrm{~cd}$ & $8.6 \mathrm{a}$ \\
\hline & Miscane & $\mathrm{PC}$ & $547.4 \mathrm{a}$ & $56.9 \mathrm{e}$ & $7.2 \mathrm{~b}$ \\
\hline & Giant miscanthus & FR & $303.2 \mathrm{e}$ & $86.1 \mathrm{abc}$ & $4.0 \mathrm{c}$ \\
\hline & Giant reed & FR & $358.8 \mathrm{~cd}$ & $77.7 \mathrm{bcd}$ & $7.1 \mathrm{~b}$ \\
\hline & Miscane & FR & $545.2 \mathrm{a}$ & $63.4 \mathrm{de}$ & $6.1 \mathrm{~b}$ \\
\hline & Giant miscanthus & SR & $192.5 \mathrm{f}$ & $90.7 \mathrm{ab}$ & $1.5 \mathrm{~d}$ \\
\hline & Giant reed & SR & $330.3 \mathrm{de}$ & $79.6 \mathrm{bcd}$ & $4.5 \mathrm{c}$ \\
\hline & Miscane & SR & $427.6 \mathrm{~b}$ & $69.0 \mathrm{de}$ & $4.5 \mathrm{c}$ \\
\hline
\end{tabular}

${ }^{\text {aPC }}=$ plant-cane; $\mathrm{FR}=$ first-ratoon; $\mathrm{SR}=$ second-ratoon; ${ }^{\mathrm{b}}$ Variable means within an irrigation treatment followed by a common letter do not differ significantly at $\alpha=0.05$ using Tukey's HSD.

Giant miscanthus leaf IVDMD concentration was comparable to that of single-cut per year, whole-plant switch grass in West Virginia [35]. Giant reed leaf and stem IVDMD compared favorably to the $541 \mathrm{~g} \cdot \mathrm{kg}^{-1}$ and $<290 \mathrm{~g} \cdot \mathrm{kg}^{-1}$, respectively, reported for giant reed by [24]. Similarly, miscane leaf $\left(520 \mathrm{~g} \cdot \mathrm{kg}^{-1}\right)$ and stem $\left(507 \mathrm{~g} \cdot \mathrm{kg}^{-1}\right)$ IVDMD observed in this study are consistent with an absence of tissue differences reported by [34] in Florida. However, the observed IVDMD of giant miscanthus leaves and stems, and giant reed stems, would be among the lowest in a wide range of reported values (280 to $740 \mathrm{~g} \cdot \mathrm{kg}^{-1}$ ) for C4 grasses [25] [26].

Like many traditional livestock feeds, green-harvested tissues could be fed fresh-chopped or ensiled [11] [36]. Steer weight gain was adequate when freshchopped sugarcane was fed at $30 \%-40 \%$ of the total diet, but performance decreased when the dietary proportion was $>60 \%$ [36]. This suggests that sugarcane is similar to other roughage sources (e.g. cottonseed hulls) when fed in steer fattening diets, but it should not be a major component of the diet. Ensiling chopped sugarcane decreases total digestible nutrient concentration, due to conversion of sugar to alcohols, therefore, silage is better for maintenance rather 
than for increasing stocker cattle weights [11]. Incubation of sugarcane bagasse with white-rot fungi (i.e. Lentinula edodes, Ceriporiopsis subvermispora) that selectively degrade lignin may substantially increase IVDMD [37], although the effect of such biological degradation on livestock intake was not assessed and the practicality of such technology to improve livestock feed quality is unknown.

\subsection{Acid Detergent Lignin}

Giant miscanthus and giant reed had greater leaf ADL concentrations ( $>91.5$ $\left.\mathrm{g} \cdot \mathrm{kg}^{-1}\right)$ than miscane $\left(<80.2 \mathrm{~g} \cdot \mathrm{kg}^{-1}\right)$ and any other feedstock source in this study (Table 2). Similarly, giant miscanthus stem ADL $\left(>86.1 \mathrm{~g} \cdot \mathrm{kg}^{-1}\right)$ was consistently greater than that of miscane $\left(<69.0 \mathrm{~g} \cdot \mathrm{kg}^{-1}\right)$. In contrast, giant reed stem ADL concentration was only greater $(\mathrm{P}<0.05)$ than that of miscane in $\mathrm{PC}$ but not in ratoon crops. Averaged across treatments, leaf tissue $\left(97.3 \mathrm{~g} \cdot \mathrm{kg}^{-1}\right)$ had significantly greater ADL than stem tissue $\left(77.0 \mathrm{~g} \cdot \mathrm{kg}^{-1}\right)$. Leaf and stem ADL did not change $(P \geq 0.05)$ over the course of three seasons, except for giant miscanthus leaves, which became significantly more lignified. Concentrations of ADL were within the range (20 to $115 \mathrm{~g}^{\mathrm{kg}} \mathrm{kg}^{-1}$ ) previously reported for various $\mathrm{C} 4$ grasses

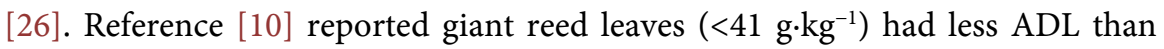
stems $\left(90 \mathrm{~g} \cdot \mathrm{kg}^{-1}\right)$, whereas ADL observed in this study averaged $109 \mathrm{~g} \cdot \mathrm{kg}^{-1}$ for leaves and $76.5 \mathrm{~g} \cdot \mathrm{kg}^{-1}$ for stems across all seasons.

Lignin is the major non-polysaccharide component of plant cell walls, reduces digestibility of polysaccharides through cross-linkages, and is virtually indigestible by rumen microorganisms [18] [33]. Lignin is high in combustible energy, similar to that of cellulose [38], and the values we found should not cause excessive tar production during gasification [39].

\subsection{Nitrogen Concentration}

Giant reed had greater $(\mathrm{P}<0.05)$ leaf $\mathrm{N}$ concentrations $\left(16.1\right.$ to $\left.27.6 \mathrm{~g} \cdot \mathrm{kg}^{-1}\right)$ than

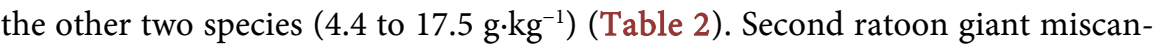
thus had the lowest leaf $\mathrm{N}\left(4.4 \mathrm{~g} \cdot \mathrm{kg}^{-1}\right)$ and stem $\mathrm{N}\left(1.5 \mathrm{~g} \cdot \mathrm{kg}^{-1}\right)$ concentrations among species and crops. Leaf and stem $\mathrm{N}$ concentrations were lower in ratoon than PC for giant miscanthus and giant reed, but not miscane. Second ratoon leaf and stem $\mathrm{N}$ concentrations were also lower than $\mathrm{PC}$ for each species, suggesting a decrease in $\mathrm{N}$ uptake in ratoon crops and greater $\mathrm{N}$-use efficiency with crop age. This was particularly evident for giant miscanthus considering its relatively high yields [27]. Decreases in $\mathrm{N}$ concentration in giant miscanthus from PC to ratoon crops were also previously observed [40].

Across diverse species, bioenergy feedstocks can be highly variable in $\mathrm{N}$ concentrations, ranging from 0.5 [Sequoia sempervirens (Lamb. ex D. Don) Endl. wood] to $30.4 \mathrm{~g} \cdot \mathrm{kg}^{-1}$ (Triticum aestivum L. dust) [41]. Tissue-N is usually considered an anti-quality attribute in combustible feedstocks, as concentrations of 10 $\mathrm{g} \cdot \mathrm{kg}^{-1}$ or greater can necessitate NOx removal at thermochemical conversion facilities [41]. On that basis alone, leaf residue would be less preferred as a combustible feedstock than stem tissue, except for SR giant miscanthus leaves. In 
practice, however, while coal contains more $\mathrm{N}\left(159 \mathrm{~g} \cdot \mathrm{kg}^{-1}\right)$ than switchgrass (8.7 $\left.\mathrm{g} \cdot \mathrm{kg}^{-1}\right)$, blending coal with a second-generation feedstock is an approach to reduce total NOx emissions from utility boilers compared to coal-firing alone [8]. A similar approach might be taken with high-N bioenergy feedstocks for combustion.

Conversely, plant proteins are a beneficial attribute in livestock feed, and are often expressed as CP [42]. Data presented herein are consistent with previous findings [34] in that leaves of mature plants have substantially greater $\mathrm{CP}$ concentration than stems. Except for SR giant miscanthus (28 g. $\left.\mathrm{kg}^{-1} \mathrm{CP}\right)$, leaf CP concentrations (calculated based on $\mathrm{N}$ ) ranged from 69 to $172 \mathrm{~g} \cdot \mathrm{kg}^{-1}$, and were generally adequate for maintaining beef cattle weights of 450 to $635 \mathrm{~kg}$ mature weight [43]. Conversely, stem tissue CP levels were low across species and inadequate $\left(<54 \mathrm{~g} \cdot \mathrm{kg}^{-1}\right)$ for cattle maintenance [43].

\subsection{Total Nonstructural Carbohydrates}

A tissue $\times$ species $\times$ irrigation interaction was observed for TNC $(\mathrm{P}<0.05$; Table $1)$. Within an irrigation treatment, giant reed had greater leaf TNC concentrations (I+: $98.0 \mathrm{~g} \cdot \mathrm{kg}^{-1}$; I-: $\left.112.8 \mathrm{~g} \cdot \mathrm{kg}^{-1}\right)$ than the other two species $\left(<73.2 \mathrm{~g} \cdot \mathrm{kg}^{-1}\right)$ $(\mathrm{P}<0.05$; Table 3$)$. All three species differed significantly in stem TNC [sugarcane $\left(>247.2 \mathrm{~g} \cdot \mathrm{kg}^{-1}\right)>$ giant reed $\left(>170.9 \mathrm{~g} \cdot \mathrm{kg}^{-1}\right)>$ giant miscanthus $(<80.6$ $\left.\left.\mathrm{g} \cdot \mathrm{kg}^{-1}\right)\right]$. For all species, stem residues had greater $(\mathrm{P}<0.05)$ TNC concentrations than leaf tissues. Composed primarily of sugars and starches, TNC are important energy reserves for plants and grazing animals [33], and it was not surprising

Table 3. Total nonstructural carbohydrate (TNC), cellulose, and energy concentrations of irrigated (I+) and non-irrigated (I-) giant miscanthus, giant reed, and miscane leaf and stem tissues as affected by the tissue component by species by irrigation interaction.

\begin{tabular}{|c|c|c|c|c|c|}
\hline Irrigation & Species & Tissue & TNC & Cellulose & Energy \\
\hline & & & \multicolumn{2}{|c|}{$\left(\mathrm{g} \cdot \mathrm{kg}^{-1}\right)$} & $\left(\mathrm{MJ} \cdot \mathrm{kg}^{-1}\right)$ \\
\hline \multirow[t]{6}{*}{$\mathrm{I}+$} & Giant miscanthus & Leaf & $41.7 \mathrm{e}^{\mathrm{a}}$ & $431.3 \mathrm{a}$ & $16.8 \mathrm{~d}$ \\
\hline & Giant reed & & $98.0 \mathrm{c}$ & $389.3 \mathrm{~b}$ & $17.1 \mathrm{c}$ \\
\hline & Miscane & & $73.2 \mathrm{~d}$ & $347.1 \mathrm{c}$ & $17.0 \mathrm{c}$ \\
\hline & Giant miscanthus & Stem & $70.1 \mathrm{~d}$ & $305.6 \mathrm{~d}$ & $17.9 \mathrm{a}$ \\
\hline & Giant reed & & $170.9 \mathrm{~b}$ & $255.2 \mathrm{e}$ & $17.9 \mathrm{a}$ \\
\hline & Miscane & & $247.2 \mathrm{a}$ & $296.9 \mathrm{~d}$ & $17.4 \mathrm{~b}$ \\
\hline \multirow[t]{6}{*}{ I- } & Giant miscanthus & Leaf & $46.5 \mathrm{e}$ & $417.1 \mathrm{a}$ & $17.1 \mathrm{bc}$ \\
\hline & Giant reed & & $112.8 \mathrm{c}$ & $381.5 \mathrm{~b}$ & $16.7 \mathrm{~d}$ \\
\hline & Miscane & & $64.9 \mathrm{de}$ & $329.5 \mathrm{c}$ & $17.0 \mathrm{~cd}$ \\
\hline & Giant miscanthus & Stem & $80.6 \mathrm{~d}$ & $290.3 \mathrm{~d}$ & $17.8 \mathrm{a}$ \\
\hline & Giant reed & & $176.2 \mathrm{~b}$ & 236.7 e & $17.7 \mathrm{a}$ \\
\hline & Miscane & & $269.5 \mathrm{a}$ & $293.4 \mathrm{~d}$ & $17.3 \mathrm{~b}$ \\
\hline
\end{tabular}

${ }^{a}$ Variable means within an irrigation treatment followed by a common letter do not differ significantly at $\alpha$ $=0.05$ using Tukey's HSD. 
that miscane had greatest levels of stem TNC among species [17]. While miscane leaf TNC concentrations were slightly lower than those reported (79 to 119 $\mathrm{g} \cdot \mathrm{kg}^{-1}$ ) for sugarcane in Florida [34], giant reed leaf TNC was within that range. Despite its comparatively high TNC concentrations, mature giant reed stems would likely have low acceptability and voluntary intake by livestock due to their fibrous and woody texture.

\subsection{Fiber Constituents}

A significant tissue $\times$ species $\times$ irrigation interaction was also observed for cellulose concentrations (Table 1). However, within residue tissue type, species ranked similarly for cellulose regardless of irrigation treatment, with cellulose concentrations being greater in leaf tissue than stems for all species (Table 3). Leaf cellulose concentrations were greatest in giant miscanthus, intermediate in giant reed, and lowest in miscane (Table 3). In contrast, stem cellulose concentrations did not differ $(\mathrm{P}<0.05)$ between giant miscanthus and miscane, albeit both of which had greater cellulose concentrations than stem residue of giant reed. Cellulose concentrations of both leaf and stem tissue were consistently greater in irrigated than rainfed treatments, but differences were only significant for miscane leaf tissue ( $347.1 \mathrm{vs} 329.5 \mathrm{~g} \cdot \mathrm{kg}^{-1}$ ) and giant reed stem cellulose (255.2 vs $\left.236.7 \mathrm{~g} \cdot \mathrm{kg}^{-1}\right)$.

Structural carbohydrates (cellulose and hemicellulose) are largely composite mixtures of 5 and 6 carbon sugars, which comprise the backbone of cell walls and provide the primary source of energy in ruminant diets [11]. Neither tissue $x$ species $x$ irrigation nor year $\times$ tissue $\times$ species interactions were significant for hemicellulose, although a strong tissue $\times$ species interaction was found (Table 1). The interaction was due to greater hemicellulose concentrations in leaves but lower concentrations in stems of giant miscanthus than miscane (Table 4). Hemicellulose concentrations were not different between leaves and stems of giant reed. Similarly, previous research [10] indicated that giant reed leaf residue $\left(<318 \mathrm{~g} \cdot \mathrm{kg}^{-1}\right)$ has a greater mean hemicellulose concentration than stem tissue $\left(<260 \mathrm{~g} \cdot \mathrm{kg}^{-1}\right)$. A similar trend, i.e. greater cellulose concentrations in leaves than

Table 4. Hemicellulose and ash concentrations of giant miscanthus, giant reed, and miscane leaf and stem tissues as affected by the species $\times$ tissue interaction.

\begin{tabular}{cccc}
\hline Tissue & Species & Hemicellulose & Ash \\
\hline \multirow{2}{*}{ Leaf } & Giant miscanthus & $246.6 \mathrm{bc}^{\mathrm{a}}$ & $95.3 \mathrm{~b}$ \\
& Giant reed & $214.0 \mathrm{~cd}$ & $107.8 \mathrm{a}$ \\
& Miscane & $211.1 \mathrm{~d}$ & $92.2 \mathrm{~b}$ \\
\multirow{2}{*}{ Stem } & Giant miscanthus & $279.7 \mathrm{ab}$ & $26.9 \mathrm{c}$ \\
& Giant reed & $233.7 \mathrm{~cd}$ & $28.3 \mathrm{c}$ \\
& Miscane & $300.9 \mathrm{a}$ & $30.6 \mathrm{c}$ \\
\hline
\end{tabular}

${ }^{a}$ Variable means followed by a common letter do not differ significantly at $\alpha=0.05$ using Tukey's HSD. 
stems, was also previously reported for sugarcane [44], but not for giant reed [24].

\subsection{Ash Concentration}

For all three species, leaf tissue ash concentrations were consistently greater $\left(>92.2 \mathrm{~g} \cdot \mathrm{kg}^{-1}\right)$ than stem ash concentration $\left(<30.6 \mathrm{~g} \cdot \mathrm{kg}^{-1}\right.$; Table 4$)$. Giant reed had greater leaf ash $\left(107.8 \mathrm{~g} \cdot \mathrm{kg}^{-1}\right)$ than giant miscanthus $\left(95.3 \mathrm{~g} \cdot \mathrm{kg}^{-1}\right)$ and miscane $\left(92.2 \mathrm{~g} \cdot \mathrm{kg}^{-1}\right)$, but species did not differ in stem ash concentration $(\mathrm{P}<0.05)$. Of 62 potential bioenergy feedstocks evaluated by [41], ash concentrations ranged from $1.8 \mathrm{~g} \cdot \mathrm{kg}^{-1}$ in redwood [Sequoia sempervirens (Lamb. ex D. Don.) Endl.] mill waste to $240 \mathrm{~g} \mathrm{~kg}^{-1}$ for weathered rice (Oryza sativa L.) straw. Those of giant reed reportedly range from 48 to $74 \mathrm{~g} \cdot \mathrm{kg}^{-1}$ [45]. The greater ash concentrations found in leaves compared to stems of giant miscanthus is consistent with findings reported by [46]. By comparison, coal has $103 \mathrm{~g} \cdot \mathrm{kg}^{-1}$ ash [47]. Low ash concentrations are a preferred attribute of bioenergy crops used for combustion due to inorganic elements causing slagging, corrosion, and fouling in power plants [48]. In a solid fuel combustor, internal ash depositions can occur at a faster rate for bioenergy crops than coal, as ash derived from bioenergy feedstocks may be more dense, less porous, and harder to remove than that of coal [49].

Based on ash concentrations, stem tissue would be preferred to leaf tissue for combustion purposes. Little is known regarding the importance of ash concentration in livestock feed, and availability of ash and inorganic minerals to ruminants fed forage diets [50]. Plant silicates constitute 70\% of switchgrass ash [51], and silicates have been implicated in reducing tissue digestibility [26]. Therefore, even within a given feedstock, it is possible to have dual-use systems both for fodder and bioenergy (e.g. leaf tissue for animal feed and stem tissue for thermochemical conversion) and within bioenergy systems (e.g. leaf tissue converted biologically and stem tissue utilized in a thermochemical platform).

Although giant miscanthus and giant reed for bioenergy are often harvested after post-freeze senescence and natural dry-down in the field, we intentionally conducted pre-freeze harvests to examine the feed/fuel dual-use potential [52]. Green harvests probably benefited livestock feed value with respect to soluble secondary cell wall constituents, such as IVDMD, N, and TNC concentrations, compared to senesced tissues [25]. However, green harvests over time may reduce stand longevity as nutrients and carbohydrates are translocated to storage tissues during maturation for the following year's regeneration [53].

\subsection{Combustible Energy Density}

A significant tissue $\times$ species $\times$ irrigation interaction was observed for combustible energy (Table 1). Specifically, energy concentration in leaves (but not stems) of the three species was affected by irrigation (Table 3). Giant miscanthus leaves from rainfed plots had greater energy concentrations than those from irrigated treatments, however, the opposite was true for giant reed leaf tissue; whereas, 
energy concentration of miscane leaves did not differ between irrigation treatments $(\mathrm{P}<0.05)$. For all three species, energy concentrations were greater in stem than leaf residues. Stem $t$ energy concentrations were lower in miscane than for the other two species, which did not different from each other.

In general, combustible energy of bioenergy grasses range from 14.8 to 19.3

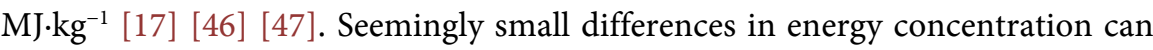
have a multiplying impact on energy yield per unit land area. In Europe, giant miscanthus had high yields of combustible energy with low $\mathrm{N}$ inputs [52]. Management practice (fertilization, plant density, or date of dormant-season harvest) also had no effect on gross energy density $\left(\mu=17 \mathrm{MJ} \cdot \mathrm{kg}^{-1}\right)$ of giant reed [54]. Given their high biomass yields, giant miscanthus and giant reed could serve as important sources of combustible energy [27].

\section{Conclusion}

Leaves and stems of bioenergy grasses may be an underappreciated crop residue and their use could reduce the competition of cropland for bioenergy production. Invasive giant reed is commonly found in relatively remote riparian areas, and is not a recommended species for agricultural use. However, giant reed leaf tissue had relatively high concentrations of IVDMD, TNC, and N, and stems had high TNC, suggesting potential value as a livestock feed. Giant miscanthus leaf tissue had high concentrations of ADL, cellulose, and low concentrations of $\mathrm{N}$ and TNC in ratoon crops, indicating greater optimal traits for combustible energy than livestock feed. Miscane stem tissue had high concentrations of IVDMD, TNC, and hemicellulose, and low combustible energy concentrations, signifying contrasting desirable attributes for forage and bioenergy feedstocks. Irrigation interacted with residue tissue (stems and leaves) per species to affect TNC, cellulose, and gross energy density, meaning intra-annual rainfall fluctuations may impact dual-use potential. Therefore, further research is needed temporally and spatially on dietary composition, acceptability, voluntary intake, and live weight gain before any of these feedstocks could be recommended for livestock feeding.

\section{Acknowledgements}

The authors gratefully acknowledge J. Brent Woolley (USDA-ARS) and Karen R. Chapman (USDA-ARS) for their technical assistance in this research. Use of the proprietary clone of giant miscanthus was made possible through a non-funded cooperative agreement (No. 58-6227-0M-F155) between Biomass Industrial Crops, Ltd. (Taunton, Somerset, UK) and USDA ARS. Peter Y.P. Tai (USDA ARS, Canal Point, Florida, deceased) provided the miscane (sugarcane clone of US84-1028). Principle funding for this research was provided by USDA ARS, Dale Bumpers Small Farms Research Center, Booneville, Arkansas through Project 6227-21310-009-00D.Mention of trade names or commercial products in this article is solely for the purpose of providing specific information and does not imply recommendation or endorsement by the USDA. 


\section{References}

[1] Ashworth, A.J., Taylor, A.M., Reed, D., Tyler, D.D., Allen, F.L. and Keyser, P.D. (2015) Life Cycle Assessment of Regional Switchgrass Feedstock Production Compared to Nitrogen Input Scenarios and Legume-Intercropping Systems. Journal of Cleaner Production, 87, 227-234. https://doi.org/10.1016/j.jclepro.2014.10.002

[2] Sanderson, M.A. and Adler, P.R. (2008) Perennial Forages as Second Generation Bioenergy Crops. International Journal of Molecular Sciences, .9, 768-788. https://doi.org/10.3390/ijms9050768

[3] McLaughlin S.B., De la Torre Ugarte, D.G., Garten, Jr., C.T., Lynd, L.R., Sanderson, M.A., Tolbert, V.R. and Wolf, D.D. (2002) High-Value Renewable Energy from Prairie Grasses. Environmental Science \& Technology, 36, 2122-2129. https://doi.org/10.1021/es010963d

[4] Hoppe, R.A., MacDonald, J.M. and Korb. P. (2010) Small Farms in the United States: Persistence under Pressure. Economic Information Bulletin No. (EIB-63), 39 p.

[5] US Department of Energy (US DOE) (2007) Energy Independence and Security Act of 2007. Renewable Fuel Standard. http://www.epa.gov/otaq/fuels/renewablefuels/index.htm

[6] US Department of Energy (US DOE) (2006) Breaking the Biological Barriers to Cellulosic Ethanol: A Joint Research Agenda. In: Houghton, J., Weatherwax, S. and Ferrell, J., Eds., A Research Roadmap Resulting from the Biomass to Biofuels Workshop, Rockville, 7-9 December 2005.

http://genomicscience.energy.gov/biofuels/b2bworkshop.shtml

[7] National Agricultural Statistics Service (NASS) (2012) Farms, Land in Farms, and Livestock Operations, 2011 Summary. Agricultural Statistics Board, US Department of Agriculture, Washington, DC.

https://www.agcensus.usda.gov/Publications/2012/Full_Report/Volume_1, Chapter 1 US/usv1.pdf

[8] Sami, M., Annamalai, K. and Wooldridge, M. (2001) Co-Firing of Coal and Biomass Fuel Blends. Progress in Energy and Combustion Science, 27, 171-214. https://doi.org/10.1016/S0360-1285(00)00020-4

[9] Boody, G., Vondracek, B., Andow, D.A., Krinke, M., Westra, J., Zimmerman, J. and Welle, P. (2005) Multifunctional Agriculture in the United States. Bioscience, 55, 27-38. https://doi.org/10.1641/0006-3568(2005)055[0027:MAITUS]2.0.CO;2

[10] Anderson, W., Casler, M. and Baldwin, B. (2008) Improvement of Perennial Forage Species as Feedstock for Bioenergy. In: Vermerris, W., Ed., Genetic Improvement of Bioenergy Crops, 347-376. https://doi.org/10.1007/978-0-387-70805-8 12

[11] Pate, F.M., Alvarez, J.J., Phillips, D. and Eiland, B.R. (1984) Sugarcane as a Cattle Feed: Production and Utilization. Institute of Food and Agriculture Sciences, University of Florida Extension, Gainesville, BUL844. http://ufdc.ufl.edu/UF00027209/00001

[12] Gould, K. (2007) Corn Stover Harvesting. Cattle Call, 12, 3-4. http://beef.msu.edu/LinkClick.aspx?fileticket=q0jUXM2MIqM\%3d\&tabid=537

[13] Graham, R.L., Nelson, R., Sheehan, J., Perlack, R.D. and Wright, L.L. (2007) Current and Potential U.S. Corn Stover Supplies. Agronomy Journal, 99, 1-11. https://doi.org/10.2134/agronj2005.0222

[14] Sivakumar, G., Vail, D.R., Xu, J., Burner, D.M., Lay, Jr. J.O., Ge, X. and Weathers P.J. (2010) Bioethanol and Biodiesel: Alternative Liquid Fuels for Future Generations. Engineering in Life Sciences, 10, 8-18. https://doi.org/10.1002/elsc.200900061 
[15] Ge, X., Burner, D.M., Xu, J., Phillips, G.C. and Sivakumar, G. (2011) Bioethanol Production from Dedicated Energy Crops and Residues in Arkansas, USA. Biotechnology Journal, 6, 66-73. https://doi.org/10.1002/biot.201000240

[16] Richard, E.J., Tew, T., Cobill, R. and Hale, A. (2008) Sugar/Energy Canes as Feed Stocks for the Biofuels Industry. In: Zalesny, R.S.J., Mitchell, R. and Richardson, J. Eds., Biofuels, Bioenergy, and Bioproducts from Sustainable Agricultural and Forest Crops: Proceedings of the Short Rotation Crops International Conference, GTR-NRS-P-31, USDA Forest Service, Northern Research Station, Delaware County, $76 \mathrm{p}$.

[17] Burner, D.M., Tew, T.L., Harvey, J.J. and Belesky, D.P. (2009) Dry Matter Partitioning and Quality of Miscanthus, Panicum, and Saccharum Genotypes in Arkansas, USA. Biomass and Bioenergy, 33, 610-619.

https://doi.org/10.1016/j.biombioe.2008.10.002

[18] Karp, A. and Shield, I. (2008) Bioenergy from Plants and the Sustainable Yield Challenge. New Phytologist, 179, 15-32. https://doi.org/10.1111/j.1469-8137.2008.02432.x

[19] Bell, G. (1997) Ecology and Management of Arundo donax, and Approaches to Riparian Habitat Restoration in Southern California. In: Brock, J.H., Wade, M., Pysek, P. and Green, D., Eds., Plant Invasions. Studies from North America and Europe, Backhuys Publishers, Leiden, 103-113.

[20] Moore, G.W., Watts, D.A. and Goolsby, J.A. (2010) Ecophysiological Responses of Giant Reed (Arundo donax) to Herbivory. Invasive Plant Science and Management, 3, 521-529. https://doi.org/10.1614/IPSM-D-10-00007.1

[21] Spencer, D.F., Liow, P.-S., Chan, W.K., Ksander, G.G. and Getsinger, K.D. (2006) Estimating Arundo donax Shoot Biomass. Aquatic Botany, 84, 272-276.

https://doi.org/10.1016/j.aquabot.2005.11.004

[22] Young, S.L., Gopalakrishnan, G. and Keshwani, D.R. (2011) Invasive Plant Species as Potential Bioenergy Producers and Carbon Contributors. Journal of Soil and Water Conservation, 66, 45A-50A. https://doi.org/10.2489/jswc.66.2.45A

[23] Mislevy, P., Martin, F.G., Adjei, M.B. and Miller, J.D. (1995) Agronomic Characteristics of US 72-1153 Energycane for Biomass. Biomass and Bioenergy, 9, 449-457. https://doi.org/10.1016/0961-9534(95)00050-X

[24] Anderson, W.F., Dien, B.S. Brandon, S.K. and Peterson, J.D. (2008) Assessment of Bermudagrass and Bunch Grasses as Feedstock for Conversion to Ethanol. Applied Biochemistry and Biotechnology, 145, 13-21. https://doi.org/10.1007/s12010-007-8041-y

[25] Coleman, S.W., Moore, J.E. and Wilson, J.R. (2004) Quality and Utilization. In: Moser, L.E., Burson, B.L. and Sollenberger, L.E., Eds., Warm-Season (C4) Grasses, American Society of Agronomy Crop Science Society of America Soil Science Society of America, Madison, 267-308.

[26] Moore, J.E. and Mott, G.O. (1973) Structural Inhibitors of Quality in Tropical Grasses. In: Matches, A.G., Ed., Anti-Quality Components of Forages, CSSA Special Publication No. 4, Crop Science Society of America, Madison, 53-98.

[27] Burner, D.M., Hale, A.L., Carver, P., Pote, D.H. and Fritschi, F.B. (2015) Biomass Yield Comparisons of Giant Miscanthus, Giant Reed, and Sugarcane Grown under Irrigated and Rainfed Conditions. Industrial Crops and Products, 76, 1025-1032. https://doi.org/10.1016/j.indcrop.2015.07.071

[28] Van Soest, P.J. (1994) Nutritional Ecology of the Ruminant. 2nd Edition, Cornell University Press, Ithaca. 
[29] Smith, D. (1981) Removing and Analyzing Total Nonstructural Carbohydrates from Plant Tissue. Bull. 2107, Wisconsin Agricultural Experiment Station, Madison.

[30] ASTM International (2010) Standard Test Method for Analysis of Coal and Coke. In: ASTM Volume 5.06: Gaseous Fuels; Coal and Coke, ASTM International Standard D5865-10a, ASTM International, West Conshohocken.

[31] Littell, R.C., Milliken, G.A., Stroup, W.W. and Wolfinger, R.D. (1996) SAS System for Mixed Models. AS Institute Inc., Cary.

[32] SAS Institute (2009) SAS/STAT User's Guide. Release 9.2. Windows Version 5.1.2600. SAS Institute, Cary.

[33] Moore, K.J. and Hatfield, R.D. (1994) Carbohydrates and Forage Quality. In: Fahey, G.C.J., Moser, L.E., Martens, D.R. and Collins, M., Eds., Forage Quality, Evaluation, and Utilization, American Society of Agronomy Crop Science Society of America Soil Science Society of America, Madison, 229-280.

[34] Mislevy, P., Adjei, M.B., Martin, F.G. and Miller, J.D. (1993) Response of US 72-1153 Energycane to Harvest Management. Proceedings-Soil \& Crop Science Society of Florida, 52, 27-32.

[35] Balasko, J.A., Burner, D.M. and Thayne, W.V. (1984) Yield and Quality of Switchgrass Grown without Soil Amendments. Agronomy Journal, 76, 204-208. https://doi.org/10.2134/agronj1984.00021962007600020009x

[36] Velik, M., Baumung, R. and Knaus, W.F. (2008) Maize Silage as an Energy Supplement in Organic Dairy Cow Rations. Renewable Agriculture and Food Systems, 23, 155-160. https://doi.org/10.1017/S1742170507002104

[37] Okano, K., Iida, Y., Samsuri, M., Prasetya, B., Usagawa, T. and Watanabe T. (2006) Comparison of in Vitro Digestibility and Chemical Composition among Sugarcane Bagasses Treated by Four White-Rot Fungi. Animal Science Journal, 77, 308-313. https://doi.org/10.1111/j.1740-0929.2006.00353.x

[38] Gani, A. and Naruse, I. (2007) Effect of Cellulose and Lignin Content on Pyrolysis and Combustion Characteristics for Several Types of Biomass. Renewable Energy, 32, 649-661. https://doi.org/10.1016/j.renene.2006.02.017

[39] Panopoulos, K.D., Fryda, L.E. and Kakaras. E. (2007) Atmospheric Fluidized Bed Gasification of Promising Biomass Fuels in Southern European Regions. Thermal Science, 11, 5-15. https://doi.org/10.2298/TSCI0701005P

[40] Clifton-Brown, J.C. and Lewandowski, I. (2002) Screening Miscanthus Genotypes in Field Trials to Optimise Biomass Yield and Quality in Southern Germany. European Journal of Agronomy, 16, 97-110. https://doi.org/10.1016/S1161-0301(01)00120-4

[41] Ebeling, J.M. and Jenkins, B.M. (1985) Physical and Chemical Properties of Biomass Fuels. Transactions of the ASAE, 28, 898-902. https://doi.org/10.13031/2013.32359

[42] Nelson, C.J. and Moser, L.E. (1994) Plant Factors Affecting Forage Quality. In: Fahey, G.C.J., Moser, L.E., Martens, D.R. and Collins, M., Eds., Forage Quality, Evaluation, and Utilization, American Society of Agronomy Crop Science Society of America Soil Science Society of America, Madison, 115-154.

[43] National Research Council (NRC) (1996) Nutrient Requirements for Beef Cattle. 7th Edition, The National Academies Press, Washington DC.

[44] Kevelenge, J.E.E., Said, A.N. and Kiflewahid, B. (1983) The Nutritional Value of Four Arable Farm By-Products Commonly Fed to Dairy Cattle by Small-Scale Farmers in Kenya. I. Organic Structural Components and in Vitro Digestibility. Tropical Animal Production, 8, 162-170.

[45] Lewandowski, I. and Kicherer, A. (1997) Combustion Quality of Biomass: Practical 
Relevance and Experiments to Modify the Biomass Quality of Miscanthus $x$ giganteus. European Journal of Agronomy, 6, 163-177. https://doi.org/10.1016/s1161-0301(96)02044-8

[46] Lewandowski, I., Scurlock, J.M.O., Lindvall, E. and Chistou, M. (2003) The Development and Current Status of Perennial Rhizomatous Grasses as Energy Crops in the US and Europe. Biomass and Bioenergy, 25, 335-361.

https://doi.org/10.1016/S0961-9534(03)00030-8

[47] Aerts, D.J., Bryden, K.M., Hoerning, J.M. and Ragland, K.W. (1997) Co-Firing Switchgrass in a $50 \mathrm{MW}$ Pulverized Coal Boiler. Proceedings of 59 th Annual American Power Conference, Vol. 59, Chicago, 1-3 April 1997, 1180-1185.

[48] Monti, A., Di Virgilio, N. and Venturi. G. (2008) Mineral Composition and Ash Content of Six Major Energy Crops. Biomass and Bioenergy, 32, 216-223. https://doi.org/10.1016/j.biombioe.2007.09.012

[49] Baxter, L.L. (1993) Ash Deposition during Biomass and Coal Combustion: A Mechanistic Approach. Biomass and Bioenergy, 4, 85-102. https://doi.org/10.1016/0961-9534(93)90031-X

[50] Spears, J.W. (1994) Minerals in Forages. In: Fahey, G.C.J., Moser, L.E., Martens, D.R. and Collins, M., Eds., Forage Quality, Evaluation, and Utilization, American Society of Agronomy Crop Science Society of America Soil Science Society of America, Madison, 281-317.

[51] Klass, D.L. (1998) Biomass for Renewable Energy, Fuels, and Chemicals. Academic Press, San Diego, 1-651. https://doi.org/10.1016/B978-012410950-6/50003-9

[52] Heaton, E., Voigt, T. and Long, S.P. (2004) A Quantitative Review Comparing the Yields of Two Candidate C4 Perennial Biomass Crops in Relation to Nitrogen, Temperature and Water. Biomass and Bioenergy, 27, 21-30. https://doi.org/10.1016/j.biombioe.2003.10.005

[53] Wilson, D.M., Heaton, E.A., Liebman, M. and Moore, K.J. (2013) Intraseasonal Changes in Switchgrass Nitrogen Distribution Compared with Corn. Agronomy Journal, 105, 285-294. https://doi.org/10.2134/agronj2012.0233

[54] Angelini, L.G., Ceccarini, L. and Bonari, E. (2005) Biomass Yield and Energy Balance of Giant Reed (Arundo donax L.) Cropped in Central Italy as Related to Different Management Practices. European Journal of Agronomy, 22, 375-389. https://doi.org/10.1016/j.eja.2004.05.004

\section{Submit or recommend next manuscript to SCIRP and we will provide best service for you:}

Accepting pre-submission inquiries through Email, Facebook, LinkedIn, Twitter, etc. A wide selection of journals (inclusive of 9 subjects, more than 200 journals) Providing 24-hour high-quality service User-friendly online submission system Fair and swift peer-review system Efficient typesetting and proofreading procedure Display of the result of downloads and visits, as well as the number of cited articles Maximum dissemination of your research work

Submit your manuscript at: http://papersubmission.scirp.org/

Orcontact as@scirp.org 